\title{
Baruk, A Traditional House of Bidayuh in Borneo, Its Space Related to Structure
}

\author{
Yunitha $^{1 *}$, Mandarin Guntur ${ }^{2}$ \\ ${ }^{1}$ Traditional Architecture Laboratory Department of Architecture, The University of Palangka Raya, Palangka Raya \\ 73111, Indonesia \\ ${ }^{2}$ Center for Housing and Settlement Studies The University of Palangka Raya, Palangka Raya 73111, Indonesia \\ *Corresponding author.Email: ozzora.magenta@gmail.com
}

\begin{abstract}
Nowadays, not all traditional buildings are still standing firmly on. Many of them have disappeared by nature disruption or by cultural distillation. This study aims to promote Baruk spaces meaning as a traditional house of Bidayuh, who settled in the western part of Borneo Island. Through its structures have proffered the knowledge on how important to preserve Baruk (its forms, elements, and functions) as a part of Dayak cultural heritages. The method of this research based on descriptive analyses and qualitative. At first, the study investigates Baruk spaces through critical comparisons of the architectural theories and its space experiences that have delivered some conclusions depicted Baruk space structure. Then, it reviews to find actual interrelationship among function, image, code, form, and material of architectural elements. Finally, the semiology approach used to explain communication on its structure in order to get its space meaning. Investigation at the Bidayuh villages in Serian, Bau, and data collection through pictures, sketches, and some interviews within the Kampung Budaya Sarawak, have altogether contributed to this study. The study argues that Baruk, in its primary function, tends to fulfill its connotation function rather than its denotation function. Keywords: Bidayuh, Baruk, space, structure
\end{abstract}

\section{INTRODUCTION}

Since the first decade of the nineteenth century, Borneo's longhouse and its cultures have enchanted many people from outside. However, the deep version of the traditional building that mostly known from western country transcripts incompletely depicted of those buildings as architectural knowledge. In reality, they were mostly using ethnology methods in general rather than the architectural approach in detail to observe the religion and life of native groups such as Bidayuh, Benuaq, Iban, Kayan, Kenyah, Kajang, Malanau, Maloh, Ngaju, Rungus, Taman and others or notably called as Dayak [1]. Therefore, this study focuses on how the Bidayuh formed its spaces refer to the structure within architectural viewpoints based on some literature relate to other Dayak architectures.

Bidayuh is mostly lived in Sarawak, Malaysia, and West Kalimantan, Indonesia. The most prominent house of Bidayuh community is a longhouse or compound with several longhouses and a head house called Baruk. Baruk is where ceremonies held and where young men and bachelors settle in. Longhouses are for families, and when boys come of age, he stayed in Baruk until the time when he marries and will then move in with his wife's family. Bidayuh built their houses used an axe and a knife, all raised on posts and commonly two or three meters high and forty or fifty meters long. The floor material came from the lath of large bamboos that might nearly flat around five centimeters wide, and these firmly tied down using rattan to the joints beneath [2]. Bamboo usually used to make walkways from village to villages, to their farms and suspension bridges over the rivers as well as flowed water to the longhouse [2]. Therefore, the unique styles of Bidayuh housing is unusual to other Dayak architectures in Borneo.

\subsection{Issue}

Nowadays, not all traditional buildings are still standing firmly on; many of them have extinct by nature disruption or by cultural distillation. Moreover, most people of Bidayuh are not living in Baruk anymore [1]. Therefore, to preserve one of the indigenous architectures in Borneo, this study is important. In addition, elaboration of the space meaning through Baruk structure have no much exposed by architect scholars.

\subsection{Aims}

This study aim to promote Baruk spaces meaning as a traditional house of Bidayuh who lived in western part of Borneo Island. Through its structures have proffered the knowledge on how important to preserve Baruk (its forms, elements and functions) as a part of Dayak cultural heritages. 


\subsection{Methods}

This research used descriptive analyses and qualitative methods. At first, the study investigates Baruk spaces through critical comparisons of the architectural theories and its space experiences that have resulted in some conclusions depicted Baruk space structure. Then, it reviews to find actual interrelationship among function, image, code, form, and material of architectural elements. Finally, the semiology approach used to explain communication on its structure in order to get its space meaning. Investigation at the Bidayuh villages in Serian, Bau, and data collection through pictures, sketches, and some interviews within the Kampung Budaya Sarawak, have altogether contributed to this study.

\section{ITS SPACE}

\subsection{Its Space Concepts of Architecture}

In the traditional concept, some theories of space fuse within the complexity of human belief and their experiences. Meanwhile, Baruk as a traditional building of Bidayuh presents in traditional space, not only the conception but also the perception of space. The perception of space comes out from phenomena, objects of the space and the orientation (attitude) to the same things [3]. Baruk is a building that imagined as a men's house or a head house [4]. The phenomena of male or adolescent men should occupy a Baruk, have made Baruk as a men orientation. It shows a connection between the value system and action to manifest architectural forms [5].

On the one hand, Bidayuh can distinguish and separate space using the cognitive process of their mind scheme ${ }^{1}$. These schemes as a cognitive mapping ${ }^{2}$ in where people be able to acquire, make a code, store, recall, and decode information regarding the relative location and attributes of the physical environment [6]. Bidayuh also believes in the myth of life and death [1]. Mythical space defines through two-way views [7], first, as a conceptual extension of the familiar and workday space given by direct experience. Second, as a component in a worldview of cosmology. The Bidayuh believed an evil spirit to cause misfortune and illness. Hence, disallow to provoke them by setting down various rules and a period of restrictions,

\footnotetext{
${ }^{1}$ Rapoport [5] explained that the scheme (thoughtful scheme) is a basic of man mind proceed in order to make the world more meaningful through implemented rules on it. The rules here is intend to as cognitive rules that reached through classifying, giving the name as well as distinguishing the place and space.

${ }^{2}$ Lang [6] noted that cognitive mapping as a basic component in human adaptation and as a requisite for human survival and in everyday behavior. The individual answering two basic questions quickly and efficiently through a mechanism. (1) Where valued things are; (2) How to get there from where he is.
}

usually after a $\mathrm{Gawai}^{3}$ ceremony or after the death. On the other hand, they also believed in the existence of forces or 'soul' in things and nature [2]. For Bidayuh, funeral practices are mostly brief and straightforward, therefore the architecture related to the funeral so few compare to their daily experiences [2,8,9].

Bidayuh is a permanent group that depends on hill paddy cultivation [1]. Besides practiced shifting cultivation, they also grew fruit trees and vegetables, collected jungle fruits and honey for food, as well as hunted and fished [2]. Those activities made limitations on their space as the inside space [10] (see fig.1). Hence, it aroused a conception regarding inside space and outside [11]. It means the Bidayuh realm at that time mostly surrounded their cultivation and hill. In the past, almost all indigenous group of Dayak practiced shifting cultivation and searching for new lands. At that time, Iban and Kayan were the most frightening evaded tribes for Murut, Kelabit, and Bidayuh; therefore, they recoiling into the mountains and down-rivers to save their life [12].

Bidayuh settled far away from the beach $[2,12]$. So, where are their space came from? The site of Baruk should in the village center and load a large number of residents. It must be strategic on good soil. Before erecting Baruk poles, the handler traced the wood at the four corners of the ground, and then put water in the middle of the area [4]. The ritual performs when twilight and escorts by a little incantation to find out the same signs on the ground. It is a suitable area or not to set a Baruk. In the morning, before sunrise, the former water in the ground hole will examine. If the water increases and changes the color, it means that the site is not suitable. If there is no change, the community will work together to clean the area [13]. During cleaning the area, residents are disallowed speaking in a crude manner because they will pollute the sanctity of the area $[4,14,12]$. Bidayuh village consists typically of two or three longhouses that closely built together, comprising 30-40 families with one Baruk. As a prominent feature in the village, Baruk plays a vital role in order to pray for an abundant supply of food and better yields from agricultural activities and protection and blessings from the spirits to the community. Baruk's room is mostly a meeting place where human heads and religious properties kept [2].

\footnotetext{
${ }^{3}$ Elam [13]; Geddes, [2] wrote during festivals, the Bidayuh gave offerings to appease the life forces in things and nature, which might be "resentful" towards the crops planted in their stead. As they consider the vital force of the paddy itself, it handled with especial tenderness, nursing it with rituals at every stage of its cultivation.
} 


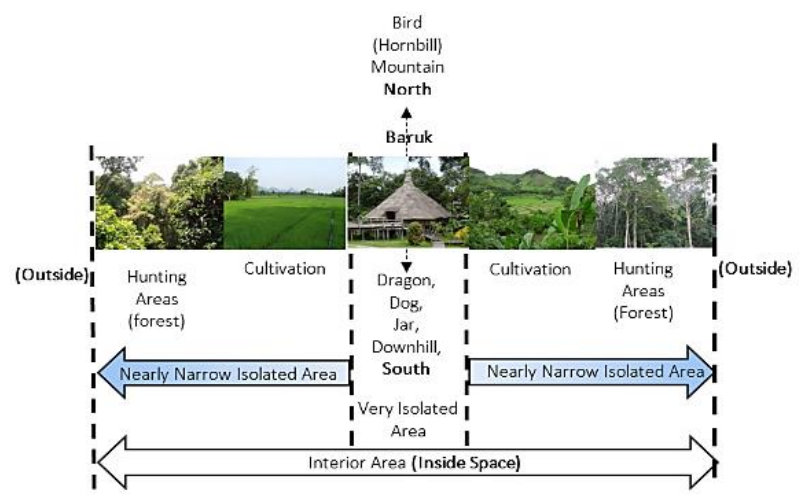

Figure 1 Space realm of Bidayuh (designed by author)

Mies Van Der Rohe [15], at the end of the second decades of the twenty-century, proclaimed, "less is more", trying to explain both traditional architecture and modern architecture have the same rationale in performs their spaces. Rohe more penetrated to the modern roots of spaces on how to make a building clean, simple, and suitably built anywhere. Meanwhile, the traditional mindset is at the same ideal ${ }^{4}$ in achieve building design but through other realms. On this side, traditional architecture mostly fulfilled all of its functions with respect to human belief, and its experience space then resulted in a building with its order. It is about how to fulfill those spaces with function, place, and material that inherent to their belief as well as their experience about nature. Hence, traditional architecture produces a unique space in certain locations [3].

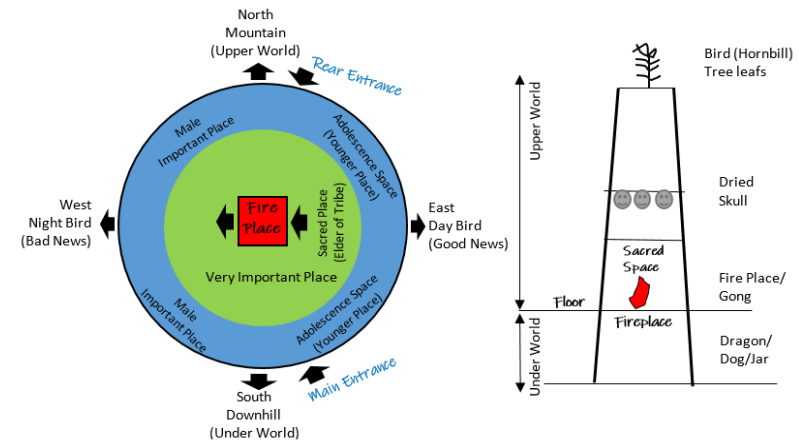

Figure 2 Space orientation of Baruk (designed by author)

\subsection{Space Analysis Perspective}

Interconnection between their experiences through nature, particularly forest, mountain, and belief have influenced their ideal to build a Baruk (see Figure 1 and 2). In traditional communities, always have a priest who is

${ }^{4}$ Alan Colquhoun [16] mentioned ideal in architecture was therefore an aim that emerged from historical experience and contingency. chosen as an elder ${ }^{5}$, a person for asking something important that connects to daily life, included asking on how to build a house. This idea as a space projection from the body of the leader [7]. He will demonstrate the spatial values from his experiences (see Figure 3). Some experiences were inherent with sensation, perception, and conception. When someone has already dominated by sensation means that emotion will be dominant. Vice versa, when the conception dominant and regardless of emotion, then thought will dominance [7].

When the leader decided to design Baruk on a particular location, he had a past design process through his intellectual realm. There is any correlation among prediction of the future, with a value system and decision criteria, which implemented within the Baruk design [6]. For Bidayuh, good will present when they choose the location of Baruk through certain ceremonies due to they had got projection that the site will give them prosperity in their future horizon $[4,14,12]$. Thus, who gave them a prediction?

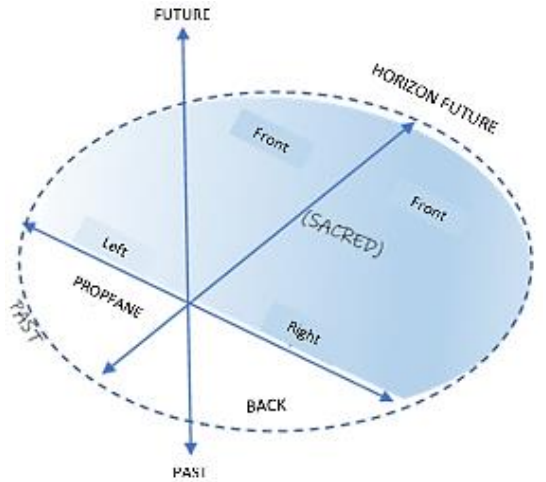

Figure 3 Space projected from the body [7]

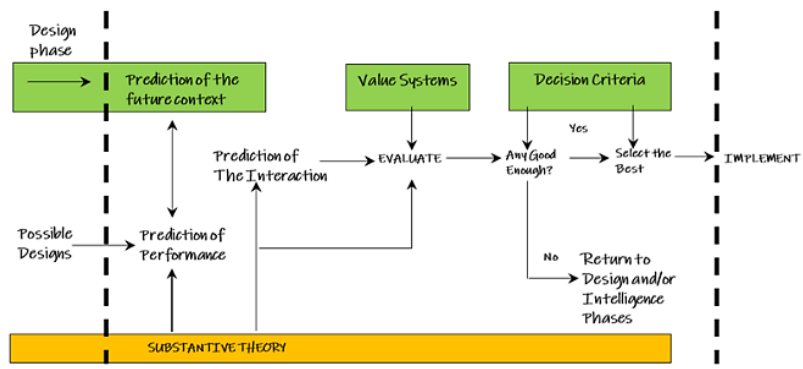

Figure 4 Intellectual activities of the choice phase of design praxis [6]

Lang [6] mentioned that it is so difficult to predict if their knowledge based on weak experiences, but Bidayuh made an excellent technique to get their prediction accomplished. For instance, when they choose a site, they used the water examine technique on the ground and check

\footnotetext{
5 King [8] mentioned the headman also called the Orang Kaya Pemanca is a "custodian of adat" and he settles dispute in the villages and has power to inflict fines in accordance with the land Dayak customs.
} 
its color on the next day off. If the color of water, which they had dropped in a hole, changed, the location predicted not well enough ${ }^{6}$. This prediction technique requires considerably more historical information than either persistence or trajectory prediction. Hence, the space experiences of Bidayuh depicts its structure as set follows (see Figure 5).

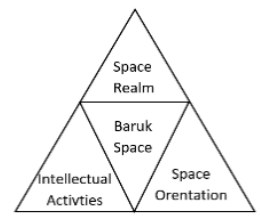

Figure 5 Bidayuh experiences to form its space (designed by author)

The space realm of Bidayuh limited all of their experiences so that they need the second experience to state their spaces. Meanwhile, intellectual activities culminate in the Bidayuh elder, who gives them the horizon about their future space. Based on the experience of Bidayuh elder or leader, they need a space orientation to state their life both in the world and in heaven. Therefore, the space in architecture is unique, according to who defines it. Then, how about its architectural structure?

\section{STRUCTURE IN ARCHITECTURE}

\subsection{Structure Concept}

The structure in architecture divides into two concepts, first as an order that arises from space, the second as building element relationship [15]. In Bidayuh, there is a structure in their society when they built a Baruk. Space is a form of a-priory structures, in case our body moves and the object is place ${ }^{7}$. In the structural field, form analysis is the basis for the materialization of structures in conformity with the deployment of its forces. It leads to the ideal exploitation of materials and minimization of the usage of the materials [17]. There are four deep structures in architecture roots interrelated to each other as Baruk parameter to prove that it has a structure: building as a container for human activities, as a modifier of the given climate, as a cultural symbol and as resource consumption [17]. As a container for human activities implies that Baruk requires its size and shape to accommodate certain

\footnotetext{
6 Lang [6] mentioned this is as a trajectory prediction assumes that past rates of change will continue in to the future. Meaning that it is a constant then tomorrow will be the same as today.

7 Pelegrino [20] revealed that space is an apriory form; it allows us to know our external reality. In the space, we represent to ourselves the objects on which we act; that is where we determine their shape, their magnitude and the relationships between them. The movement of one's own body, the transport and handling of objects, as the anchoring in a place, suppose space, a liberty in space that makes possible the dynamic of displacement as much as the stop in a place.
}

activities such as rituals, and adolescence inhabitant. In the center of Baruk contained all aspects of Bidayuh who lived on earth and in heaven through the fireplace sacred ritual. Second, building as a climatic modifier implies that its surfaces, particularly the external floor side, wall, and roof, act as barriers between interior space and the outside environment. Baruk performed this filtering role effectively in terms of heat, light, and sound control by using certain materials such as rattan, ironwood, and foliage. It also prevents the externalities factors such as animal attacking and others. Therefore, Baruk using a cone concept by modifying its stage, floor, wall, and its roof on a certain height and degree. Third, building as cultural symbol operates within Bidayuh tribe than other Dayak in Borneo, particularly on the shape of the skull house (Baruk). Because no other tribes in Borneo alike Bidayuh, Baruk is like an antithesis for Dayak in its house design. Formally, Dayaks are mostly constructed longhouse for their residential $[18,19]$ - however, Bidayuh saw further regarding a place to convey the message to deities.

Fourth, Baruk, as a consumer of resources, allows Bidayuh to widen its housing and move it out to other places with new materials to add value to certain locations (new areas). Indeed, Bidayuh can do those activities if other tribes do not attack them continually. Hence, the deployment of Bidayuh tribe merely on certain locations in Borneo, that meant they were so few in using resources. Structure in architecture also depicts how a building sends signs to the spectator on how it looks to be, how it builds to be, and how it functions to be. Therefore, in some theories, provoke architecture as if be able to communicate.

\subsection{Baruk as Communication in Architecture}

As communication in architecture [21] [15], Baruk depicts a sense of buildings. Therefore, some elements of architecture $^{8}$ present to explain this concept. Meanwhile, the structure has obvious applications to the world of architecture through the discipline of semiology- the science of signs [21]. Semiology offers a mechanism by which the built environment can be read and decode. In order to read and decode the built environment of the Bidayuh tribe as a sign, the publication of Saussure that identify Baruk to be a signifier (image) and signified (concept) explains of those relationships [22]. In his publication, Saussure wrote that signifier and signified interlocking to each other. He proposed that the sign is the main topic of semiotic (symbol), then the second as icon and index [23].

\footnotetext{
${ }^{8}$ Elements of architecture focuses on the fragments of the rich and complex architectural collage such as window, facade, balcony, corridor, fireplace, stair, escalator, and elevator [24]. Meanwhile, Alberti proposed six fundamental element of architecture; there are region, site, subdivision or plan, walling, roofing, openings [25].
} 
Table 1 Elements of Architecture Relationship [22]

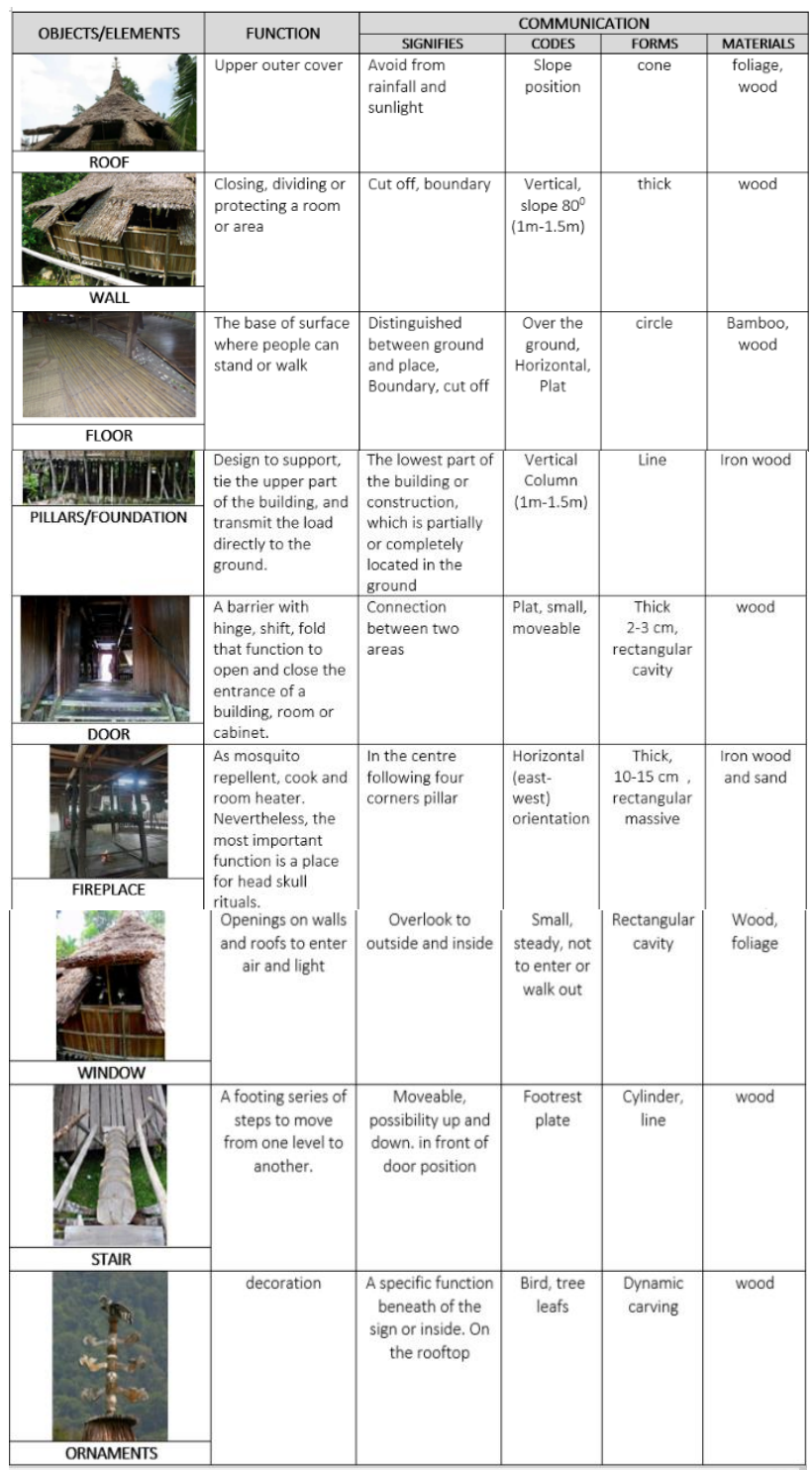

Source: Modified from Koolhas and Alberti [24,25]

In order to depict those concepts and images in Baruk elements (see Table 1), we need to reveal interrelation among them. Where function is the true of sign as the main topic of semiology as well as picturing the relations between signifier and signified [23]. It traces through the three space syntaxes of its function. First, as seen in Figure 6 , the fireplace as the main activities and the other are secondary.

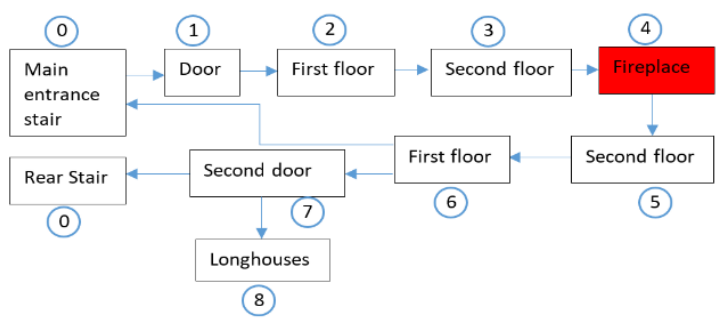

Figure 6 Space syntax on circulation pattern during ritual (designed by author)

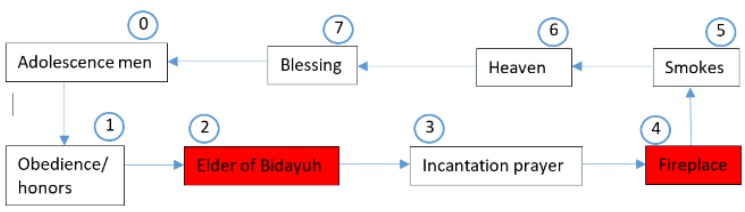

Figure 7 Space syntax reside in Baruk (designed by author)

Second, Figure 7 shows the relation among activities the adolescent men reside in Baruk, where the elder of Bidayuh as the verb and fireplace as the object. Finally, the most important space syntax in Baruk is regarding how to state the location, as explained in Figure 8. Because, through this, the whole life of the Bidayuh tribe is at stake now and in the future.

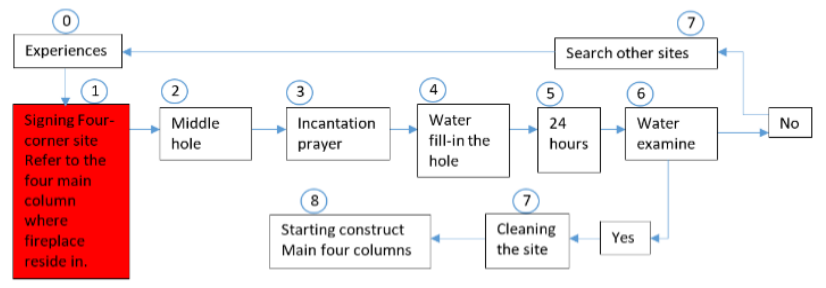

Figure 8 Space syntax to state the location of Baruk based on the intellectual realm of the leader (designed by author).

Accidentally or not, the space syntax of Baruk should seven that lied on certain spaces consecutively. Hence, it looks as a mechanism in Baruk space that controlled by functions as the main symbol (what they call as a house of the skull). Therefore, Umberto Eco distinguished denotative and connotative [21]. It also distinguishes structure to be a primary function as a functional object and as a symbolic object. In his note, both categories are potentially for losses, recoveries, and substitutions. It means that Baruk as a house needs the second semiotic as signs that fuse in signifier (image), code, form, and its material. Where form and material as an icon, then code as an index [21,23] (see Figure 9). 


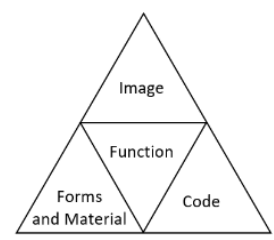

Figure 9 Function as the main semiology in Baruk (designed by author)

\subsection{Baruk as Dennotation of Architecture}

Baruk, in its communication, denotes a form of inhabitation'. Look at its roof, as the upper outer cover enables the occupant to avoid the rainfall and the heat of the sun directly (see Table 1). In reality, the roof can come in variations and models. So why with a cone? It is due to the circle floorplan. Back again, the function below the roof tells us that any something special. In this case, with a fireplace in the middle, the room should be able to canalize the smoke and lift it to the top. Therefore, to achieve a roof with conical formation, the circular wall should adapt its design.

Baruk wall denotes as a closing, dividing, or protecting an area function. As a boundary, the wall principle encloses the room fit for its activities. In Baruk, the wall only more or less 1.5 meters high over the floor that allows someone to sit and not for standing. Seeing detail, the wall of Baruk has a slope around 80 degrees to provide the possibility for leaning and allow the wind to pass through its interior. It occurs because wood plates that tied by rattan on the balk accidentally making cavities so that that wall construction can follow the circular floor properly.

The floor of Baruk designed over the stage denotes function to avoid water runoff from the mountain and to evade enemy attack $[27,12,28]$. On the other hand, the floor has denoted as a base surface, so it comes in a horizontal platform to ease manages. Baruk floor material, mostly using bamboo woven that tied to each other. Over the woven bamboo, a rattan mat covering the entire floor denotes a comfortable surface. Baruk floor comes in two levels, on the first floor, fireplace denotes for cooking and put the jars and gongs. A fireplace set in the middle of the house denotes either as a mosquito repellent or as a kitchen. The separator between the first floor and second floor is not so high that it denotes the possibility for the occupant to sit comfortably. The second floor before installation requires the smoothen boards and tied to the wall or follows the wall formation connotes as a divan or seat place [26].

${ }^{9}$ St. John [26] written all head-houses have the same appearance, built on high posts and in a circular form with a sharp colonial roof. The windows are, in fact, a large portion of the roof, raised up like the lid of a desk, during fine weather and supported by props. But then, when rain or night comes on removed, and the whole appearance is snug in the extreme, particularly when a bright fire is lit in the centre and throws a inconstant gleam an all the surrounding. Around the room are rough divans on which the men usually sit or sleep, but at night, there a cold wind and drizzling rain, a good fire kept up and the crowded near.
The stair of Baruk comes in vary depending on the floor height and location, sometimes very high for the tribe that lived near the river but sometimes only 1.5 meters high for the tribe who reside on the mountain. In certain tribes of Bidayuh on the western part of Borneo, the height of the Baruk stage reached 4-5 meters above the ground level. Nevertheless, Baruk owned at the same performing wherever its locations, particularly regarding its decoration in the culmination of the rooftop, a bird carving, and forest leaves [26].

\subsection{Baruk as Connotation of Architecture}

Baruk undoubtedly can connote a particular ideology of the function. In this communication promotes its functional capabilities or as the symbolic connotations. Roof connotes as a sign of a skull house or a house of the leader. This connotation has already attached to the cone shape that something should achieve to the culmination point. However, the roof connotes the meaning of building façade entirely and the identity of the owner.

Moreover, well known entirely of Borneo, the cone roof always connotes as a Bidayuh house. What the ideology inside of the cone roof model that promotes in Bidayuh tribe? It shows how the Bidayuh tribe was doing rituals in their house. It connotes as a cosmological define where the cone roof model as a village orientation endorsed by their limited space and orientation.

The circular wall connotes as a limited area of sacred mode, as well as an orientation boundary focuses on the center. In Baruk, the wall circularly covered the floor forces occupant orientation to the center where fireplace state. It is similar to give an honor attitude to the leader who led the ritual, or it means other connotations that gave the enemies respect or convinced that they do not haunt in a dream. Respect and honor both words that people of Bidayuh obedience in silence. Obeying means do not talk carelessly or making the sacred area paralyzed. It is also a wall in Bidayuh daily life sacred to protect them from the worst events. In other defines, the wall connotes as a boundary does not talk more than the leader thoughtful. So, people who reside in Baruk should pay attention to the leader. Responding to it, the floor of Baruk should accommodate these attitudes with circularly floor designed.

The floor of Baruk, commonly designed with a circular pattern, connotes the occupant should focus on the center [29]. Baruk floor came in two levels that separates between sacred area and non-sacred area. In the sacred area, all functions concentrated on the fireplace. The leader who led the ritual resides on the first floor supported by their adolescent men that live on the second stage floor. The floor dimension also varies; the first floor has a fixed dimension, yet the second floor is flexible. What are the values mean? It connotes a leader is a person that must be honored, while the flexible second floor is for adolescent men that connote to its growth. Why is the floor not separated far away or not interlock to each other? It 
connotes a lesson given by the leader to his descendants with a strong connection.

There are the same meaning both stair and fireplace. A stair is a way to heaven ${ }^{10}$. In connotative, people of Bidayuh seen the ground as the underworld that should not be stepped. For them, living in a high place means harmony. Stair has given them step higher toward heaven. Albeit, in Bidayuh, have emphasized the existence of heaven and god place through fireplace ceremonies. One of the offerings that god accepts is hanging head of enemies that were ever attacking them and death $[2,13]$. Therefore, the fireplace in this connotation as the same as meaning to the stairway to heaven. Due to its centralized meaning the Bidayuh's life, the fireplace is set in the middle of Baruk as their orientation and cosmological meaning as well.

\section{CONCLUSION}

The space realm of Bidayuh connotes its central life to deities on the north mountain as the upper world using Baruk in the central space of activities as the stairs of heaven. On the contrary, the down space on the south side of Baruk connotes as a useless place where the underworld settles. Meanwhile, the east side connotes the good news will come so that the front and rear door should reside. Conversely, on the west side, connotes as bad news where mourned occur, so that the fireplace orientation is from the east to the west. The smoke should blow to the west side to drive away from the bad thing. Therefore, the fireplace form comes in four corners/sides (square).

On the other hand, its space realm denotes its limited area for cultivation as the second function and hunting area as its outer space boundary toward the outside spaces. Then, Baruk in the center of its area as a house for living in harmony. Intellectual activities of the leader connote the leader as the verb who provides the best thing in Bidayuh life when he led them incantation prayer to deities through fireplace rituals. He also denotes the leader who has the ability and knowledge to decide the best thing. Space orientation connotes the whole life of Bidayuh centralizes to the Baruk as a stair to heaven through the fireplace rituals. It denotes the orientation space for adolescent men's house when they reach their ages. That threeelement of spaces of Bidayuh has given meaning to Baruk spaces' experience. Structurally, its image, code, form, and material interrelation depicts Baruk as a primary function tend to fulfill its connotation function first rather than its denotation, particularly related to the fireplace ritual in the central of Baruk. From the equations drawn between vernacular architecture itself and the architectural theory that introduced in this study have known the Bidayuh tribe spaces related to its structures as the model to preserve Baruk as the cultural heritage of Borneo in both Malaysia and Indonesia.

${ }^{10}$ Guntur [18] [28] wrote this term at the same meaning in all Bornean tribes regarding to their houses stair connotation and denotation function.

\section{ACKNOWLEDGMENT}

We owe gratitude to Kampung Budaya staff in Sarawak allowed us took some photos around the Kampung. Melayu Cultural Foundation in Sarawak for Innova driver who delivered this team when we were in Kuching. The University of Palangka Raya that funded this research. Finally, yet importantly, we are most grateful to Prof. Dr. Haji Sanib bin Haji Said, MA, and Prof. Nielson Ilan, Ph.D. from UNIMAS, who gave us a chance exploring Bidayuh data and friendship of a great many people in Sarawak that are priceless.

\section{REFERENCES}

[1] Winzeler, The Architecture of Life and Death in Borneo, University of Hawai'i Press, 2004.

[2] Geddes, W. R. Nine Dayak Nights. Singapore: Oxford University Press. 1953.

[3] Schulz, Norberg Christian. Intentions in Architecture. MIT Press. USA. 1968.

[4] Ungang, C.Baruk: Falsafah dan Pemikiran Masyarakat Bidayuh. Bangi: Medium Publications. 2014.

[5] Rapoport, A. House form and Culture, Prentice Hall, Inc., Englewood Cliffs, N.J, University of Wisconsin. USA. 1969.

[6] Lang, Jon. Creating Architectural Theory, the role of the behavioral sciences in Environmental Design. VNR Company, New York. USA. 1987

[7] Tuan, Y. Space and Place the perspective of experience, University of Minnesota Press.

Minneapolis. 1977

[8] King. V. T. The Peoples of Borneo. Oxford, UK: Blackwell. 1991.

[9] Ave, J. B. \& King, V. T. Borneo: The People of the Weeping Forest. National Museum of Ethnology, Leiden. Netherlands, ISBN 9071310280. 1986.

[10] Tschumi, Bernard. Architecture and Disjunction. Cambridge, MIT Press, USA. 1994.

[11] Heidegger, M. Building Dwelling Thinking and Poetically Man Dwells, in Poetry, Language, Though, 
Albert Hofstadter, trans. Harper \& Row. New York. USA. 1971

[12] Brooke, M. My Life in Sarawak. London: Methuen \& Co. Ltd. 1913.

[13] Elam, E. H. Land Dayaks of the Sadong District, Sarawak Museum Journal. Vol. IV (15) (1937) 373394.

[14] Beccari, O. Wanderings in the Great Forests of Borneo, New York: Oxford University Press. 1904.

[15] Broadbent, G. Design in Architecture. John Willey \& Son. USA. 1973.

[16] Colquhoun, A. Modernity and the Classical Tradition.Cambridge: MIT Press, 1989.

[17] Hillier, J Musgrove, P O'Sullivan, Knowledge and design- Environmental Design: research and practice, 1972.

[18] Mandarin Guntur, Betang, Traditional Housing of Dayak Ngaju in Central Kalimantan. BorneoKalimantan Conference V proceeding, IPAT University Malaysia Sarawak, P.117, 2009.

[19] Yunitha, Architectural Expression of Tiwah Ceremony Case Study of Dayak Ngaju Tribes Betang House in Central Kalimantan. digilib.its.ac.id. 2007.

[20] Pellegrino P, Emmanuelle P. Jeanneret Meaning of Space and Architecture of Place, Semiotica 175-1/4. (2009).

[21] Umberto Eco. A Theory of Semiotic, Bloomington: Indiana University Press, 1976.

[22] Broadbent, G, Richards Bunt, Charles Jencks. Sign, Symbol, and Architecture. John Willey \& Son. USA. 1980

[23] M. Parsaee, Moh. Parva, Bagher Karimi. Space And Place Concepts Analysis Based on Semiology Approach in Residential Architecture the Case Study Of Traditional City of Bushehr, Iran. HBRC Journal, 2014.

[24] Rem, Koolhaas. Elements of Architecture.

Taschen. USA. 2018.

[25] Hanno-Walter Kruft. A History of Architecture Theory, from Vitruvius to the Present. Princeton Architectural Press, USA. 1994.

[26] St. John, S. Life in the forest of the Far East: Travels in Northern Borneo (Vol 1). London: Smith, Elder and Co. 1863
[27] Mandarin Guntur, Tari Budayanti, Yunitha, Design of Traditional Housing: Architectural Adaptation to Climate Change in the Lake of Tundai Residential Area In Palangka Raya, Collaboration Research UPRQueensland University, unpublished by LPPM University of Palangka Raya. 2018.

[28] Mandarin Guntur, Makna Ruang pada Rumah Betang Suku Dayak Ngaju di Kalimantan Tengah: Menapak Hidup ke Nirwana Tanpa Neraka. Proceeding PESAT (Psikologi, Ekonomi, Sastra, Arsitek \& Sipil) Vol 2, 2007

[29] Steadman, JP. “Architectural Morphology, an introduction to the geometry of building plans". Pion Limited, London, UK. 1989. 